\title{
Contextual analysis of gynaecological care provided to women with physical disability
}

\author{
Análise contextual do atendimento \\ ginecológico da mulher com deficiência \\ Análisis contextual de la consulta ginecológica \\ de la mujer con discapacidad física
}

\author{
Camila Fernandes da Silva Carvalho \\ Rosineide Santana de Brito ${ }^{b}$ \\ Soraya Maria de Medeiros ${ }^{c}$
}

\begin{abstract}
This is a theoretical-reflective study that aimed to analyze the contexts associated with gynaecological care for women with physical disabilities. Discussion consisted of contextual analysis according to Hinds, Chaves and Cypress, leading to four interconnected layers: immediate, specific, general and metacontext. Analysis showed that gynaecological assistance to clients with physical disabilities is influenced by attitudinal, structural, financial and informational barriers. Other influential issues are social beliefs and stigmas and the persistence of a biomedical model, which is hegemonic in this type of assistance. Therefore, gynaecological care must be valued based on the holistic paradigm offered by a transdisciplinary team in order to provide quality care to women with physical disabilities. Descriptors: Disabled persons. Women's health services. Gynaecology.
\end{abstract}

\section{RESUMO}

Estudo teórico-reflexivo que objetivou analisar os contextos associados ao atendimento ginecológico à mulher com deficiência física. Para isso, a discussão foi embasada pela análise contextual conforme Hinds, Chaves e Cypress. De acordo com esse referencial, quatro camadas interligam-se: contexto imediato, específico, geral e metacontexto. Constatou-se que a assistência ginecológica à clientela com deficiência física é influenciada por barreiras atitudinais, estruturais, financeiras e informacionais. Somam-se, ainda, as crenças e os estigmas presentes na sociedade, bem como a persistência do modelo biomédico, hegemônico nesse atendimento. Portanto, necessita-se valorizar a consulta ginecológica com base no paradigma holístico, ofertada por uma equipe transdisciplinar, na perspectiva de uma assistência de qualidade à mulher com deficiência física.

Descritores: Pessoas com deficiência. Serviços de saúde da mulher. Ginecologia.

\section{RESUMEN}

Estudio teórico-reflexivo que objetivó analizar los contextos asociados con atención ginecológica a mujeres con discapacidades físicas. Para esto, la discusión se basó en el análisis contextual conforme Hinds, Chaves y Cypress. De acuerdo con este referencial, cuatro capas se inteconectan: contexto inmediato, específico, general y metacontexto. Se constató que la asistencia ginecológica a la clientela con discapacidad física es influenciada por barreras actitudinales, estructurales, financieras y de información. También se suman las creencias y los estigmas de la sociedad así como la persistencia del modelo biomédico, hegemónico en este servicio. Por lo tanto, se necesita valorar la atención ginecológica en base al paradigma holístico, ofrecido por un equipo transdisciplinar, en la perspectiva de una atención de calidad a la mujer con discapacidad física.

Descriptores: Personas con discapacidad. Servicios de salud para mujeres. Ginecología.
D0l: $\quad$ http://dx.doi.org/10.1590/1983-

1447.2014.04.45335 


\section{口INTRODUCTION}

In the mid-20 th century, the rights of people with physical disabilities were established by means of conventions promoted by the United Nations. The conquered acknowledgement of these rights have steadily grown since then, but when the topic is sexual and reproductive health there are obstacles due to a social stigma. Consequently, specific care to meet these needs is rarely considered due to the erroneous social belief that people with disabilities are "asexual" and are therefore discouraged from fully experiencing their sexuality ${ }^{(1-2)}$.

In Brazil, this issue was debated and documented by the Ministry of Health to promote this form of care in the healthcare system. However, public policies and the practices of these determinations are still incipient ${ }^{(3-4)}$. Consequently, women with physical disabilities do not receive the sexual and reproductive assistance they require ${ }^{(2-3)}$. Admittedly, gynaecological assistance encounters several barriers, especially in relation to physical disabilities. As a result, the question that emerged was: What are the contextual aspects that permeate gynaecological consultations of women with physical disabilities?

To answer this question, contexts associated to gynaecological assistance for women with physical disability were analysed according to the method proposed by Hinds, Chaves and Cypress, considering the studied phenomenon from the contexts in which it is inserted and promoting a global and truthful understanding of the study object. This framework led to four interconnected layers: the immediate context, which refers to relevant aspects in the present; the specific context, which are the individual and environmental aspects in the immediate past; the general context, which extends individual aspects considering those that were acquired in time, such as beliefs and life story; and the metacontext, which contemplates a broader, social and shared scope because it addresses a larger number of people, such as standards and public policies ${ }^{(5)}$.

In this study, contexts are presented in four sub-topics founded on previous knowledge on women's gynaecological care. The immediate context describes the actual gynaecological consultation of women with physical disability; the specific context is the result environmental difficulties that influence this assistance; the general context considers cultural and social influences and personal beliefs of professionals and users; and finally, the metacontext explores determining factors of the past and present through paradigms that permeate this phenomenon.

\section{- GYNAECOLOGICAL CONSULTATIONS FOR WOMEN WITH PHYSICAL DISABILITY - IMMEDIATE CONTEXT}

The gynaecological consultation is part of the women's healthcare programme and therefore includes women with some limitations. This type of care can be provided by physicians or nurses with other healthcare professionals in a transdisciplinary process. As a result, the actions of the healthcare team converge toward the patients.

The particularities of the limitations of women with physical disabilities and the involved risk factors are considered in healthcare( ${ }^{(6)}$. As with all care, gynaecological assistance must be governed from a holistic standpoint to promote the user's capacity for self-care, which includes making healthcare-related decisions with the attending professionals ${ }^{(6-7)}$.

This type of assistance includes the observance of puerperal alterations or changes resulting from menopause, tests such as cervical cytopathology and clinical breast examinations, use of contraceptives and the detection of gynaecological diseases, especially sexually transmitted diseases. Furthermore, sexuality and sexual aspects should be approached, and all aspects related to violence ${ }^{(6)}$. However, the presence of women with physical disabilities in gynaecological consultation rooms is still scarse due to obstacles in relation to holistic assistance.

\section{INSTITUTIONAL BARRIERS TO GYNAECOLOGICAL ASSISTANCE - SPECIFIC CONTEXT}

Literature shows that women with physical disabilities are less likely to seek gynaecological assistance due to attitudinal, structural, financial and information barriers ${ }^{(8)}$. Clinics and other healthcare institutions are usually structurally unprepared to receive women with these limitations, which forces these users to seek help to access these services. They encounter problems in relation to physical space in the consultation rooms, difficulties in getting undressed and transferring to the examination table, and finding an appropriate position for the procedure. Furthermore, equipment is not always adaptable to the physical conditions of these patients ${ }^{(9)}$.

Difficulty in accessing medical centres is also related to location, considering that the best quality services are concentrated in urban cities ${ }^{(10-11)}$. Consequently, women who reside in more distant areas encounter transportation difficulties and may be discouraged to continue seeking assistance. 
Information barriers occur when healthcare professionals and patients do not exchange information or knowledge leading to a lack of adherence to testing. It was observed that if these women periodically went to consultations, healthcare professionals would be able to guide and encourage them to proceed with the necessary tests ${ }^{(10)}$. However, analysis showed that, in addition to these barriers, other aspects contribute to the absence of women with physical disabilities in gynaecological consultation rooms.

\section{口INDIVIDUAL BARRIERS TO FULL GYNAECOLOGICAL CARE - GENERAL CONTEXT}

According to the World Health Organization, women with disabilities are prone to have unstable relationships, lower education levels and less favourable financial conditions ${ }^{(2)}$. These characteristics influence the frequency of these women in gynaecological consultation rooms, as lower educational levels can impair their understanding of the importance of these consultations that, added to the financial conditions, can create obstacles that prevent women with physical disabilities from seeking healthcare services ${ }^{(10)}$.

Another individual barrier that should be considered is the negligence of users in relation to gynaecological testing for early detection, based on the allegation that they do not present symptoms and these tests are therefore unnecessary ${ }^{(12)}$. In this sense, the culture of seeking healthcare services in the presence of symptoms is evident in society and characteristic of the biomedical model. This characteristic leads to the assumption that prevention of complications and the promotion of health must be stimulated by the healthcare team, which must notify the population on the importance of early detection of problems that can be asymptomatic. Another factor that discourages these women are the costs of being tested when they do not have a health plan or when the health plan does not offer full coverage in relation to gynaecological screening, which configures another financial barrier ${ }^{(0,12)}$.

Another obstacle is related to the healthcare professionals who provide gynaecological care to women with physical disabilities. Some of these professionals have an asexual image of these women and do not refer them to gynaecological screening ${ }^{(8,11)}$. It should be noted that the absence of appropriate guidelines for these women in relation to their sexuality and sexual activity create gaps in assistance and increase their vulnerability ${ }^{(8)}$ and exposure to health problems. Preconceived concepts and attitudes of those who provide care to women with physical disabilities tend to discourage follow-up and maintenance of subsequent consultations.

Healthcare professionals can also lack the knowledge needed to conduct gynaecological procedures on this population group. This becomes evident when the consultations focus both on the disability as the required duration of consultations, which is different between the users with or without limitations ${ }^{(13)}$. In light of this observation, the current culture of quick consultations in order to cover a greater number of patients negatively influences the quality of assistance, especially when users require patience, care and attention in relation to possible difficulties during each stage of the consultation.

It was also observed that contraception is culturally affected by the prejudice of healthcare professionals, and even of women with disabilities. Both providers and users often believe that sterilization is the only form of contraception that prevents possible transmission of diseases to the child ${ }^{(11)}$. However, these issues must be discussed between professionals and users according to the contexts that involve the disability and the desires of each patient.

In general, there is a need to break stigmas and prejudice in relation to the sexual and reproductive health of women with disabilities, granting them freedom over their bodies and their options and respecting their biological, financial, social, cultural and religious contexts.

\section{DIFFICULTIES IN PROVIDING GYNAECOLOGICAL CARE IN A GLOBAL CONTEXT - METACONTEXT}

The biomedical paradigm that invades university classrooms in the mid-21 $1^{\text {st }}$ century hegemonically persists in the education of healthcare workers. These professionals usually cannot interconnect the contexts of human beings and their individuality. The expected care to provide to women with disabilities is chiefly a reflection of the counter-hegemonic paradigm that calls for holism, transdisciplinarity and the appreciation of the complexity that involves this social group.

Consequently, continued education should be promoted to meet the needs of women with physical disabilities, especially in relation to gynaecological consultations. This education should contemplate holistic assistance in terms of screening and techniques that respect the limitations of these users. Active listening and promptness to respond to their questions and fears allows the creation a professional-user bonds, and ensures the adherence of women with disabilities to consultations and follow-up. It is also 
important to orientate healthcare professionals in terms of the eventual problems these women may encounter according to their physical disability ${ }^{(6-7,70)}$.

\section{aINAL CONSIDERATIONS}

Contextual analysis of the phenomenon that involves gynaecological assistance for women with physical disabilities showed that the immediate, specific and general contexts are influenced by the metacontext. The biomedical paradigm contributes to the maintenance of barriers around the protagonists of consultations and the environment in which the consultations are conducted. Although Brazil is a pioneer in the establishment of healthcare policies for people with disabilities, their effective implementation is still hindered due to gaps in gynaecological assistance for this population. There is also a lack of scientific production required to discuss this issue in Brazil.

In addition, analysis revealed the need for policies that further support the rights of women with physical disabilities. It is therefore imperative to adopt inclusive and immediate strategies that promote self-care practices in these women. There is also the need to train professionals, especially nurses, who can be responsible for providing healthcare education in this practice area that creates awareness in the population and reduces social prejudice.

The increased observance of gynaecological consultations together with holistic assistance provided by a transdisciplinary team can promote healthcare. In this regard, assistance must focus on women with physical disabilities, their families and the society in which they are inserted.

\section{REFERENCES}

1. United Nations. Convention on the rights of persons with disabilities and optional protocol. New York; 2006.

2. World Health Organization. Promoting sexual and reproductive health for persons with disabilities: WHO/UNFPA guidance note. Geneva; 2009.

\section{Author's address:}

Camila Fernandes da Silva Carvalho

Av. Ayrton Senna, 1100, bl. 7, ap. 1002, Nova Parnamirim

59151-900, Parnamirim, RN

E-mail: camilafscarvalho@gmail.com
3. Ministério da Saúde (BR). Direitos sexuais e reprodutivos na integralidade da atenção à saúde de pessoas com deficiência. Brasília; 2009.

4. Santos, LFM, Bento PASS, Telles AC, Rodrigues RF, Xavier RB. Mulheres com deficiência: reflexões sobre a trajetória das políticas públicas de saúde. Rev Enferm UFPE on line [Internet]. 2013 [citado 31 out 2014];7(7):4775-81. Available in: http://www.revista.ufpe.br/revistaenfermagem/index.php/revista/article/ download/4384/6632

5. Hinds PS, Chaves DE, Cypress SM. Context as a source of meaning and understanding. Qual Health Res. 1992;2(1):61-74.

6. Sudduth A, Linton D. Gynecologic care of women with disabilities: implications for nurses. Nurs Womens Health [Internet]. 2011 [cited 2013 Jul 09];15(2):138-48. Available in: http://onlinelibrary.wiley.com/doi/10.1111/j.1751-486X.2011.01622.x/pdf

7. Robey KL, Minihan PM, Long-Bellil LM, Hahn JE, Reiss JG, Eddey GE. Teaching health care students about disability within a cultural competency context. Disabil Health J [Internet]. 2013 [cited 2014 Aug 18];6(4):271-9. Available in: http://www.sciencedirect.com/science/article/pii/S1936657413000964

8. Gibson BE, Mykitiuk R. Health care access and support for disabled women in Canada: falling short of the UN Convention on the Rights of Persons with Disabilities: a qualitative study. Women's health issues [Internet]. 2012 [cited 2014 Aug 18];22(1):e111-8. Available in: http://www.sciencedirect.com/science/ article/pii/S1049386711001757\#

9. Courtney-Long E, Armour B, Frammartino B, Miller J. Factors associated with self-reported mammography use for women with and women without a disability. J Womens Health [Internet]. 2011 [cited 2013 Jul 09];20(9):1279-86. Available in: http://online.liebertpub.com/doi/ pdf/10.1089/jwh.2010.2609

10. Huang KH, TsaiWC, Kung PT. The use of Pap smear and its influencing factors among women with disabilities in Taiwan. Res Dev Disabil [Internet]. 2012 [cited 2013 Jul 09];33(2):307-14. Available in: http://www.sciencedirect.com/ science/article/pii/S0891422211003520

11. Frohmader C, Ortoleva S. The sexual and reproductive rights of women and girls with disabilities. In: ICPD Beyond 2014 Conference on Human Rights and Sexual and Reproductive Rights; 2013 Jul 7-10; The Netherlands. ICPD; 2013. 18 p.

12. Drew JAR, Short SE. Disability and Pap smear receipt among U.S. women, 2000 and 2005. Perspect Sex Reprod Health [Internet]. 2010 [cited 2013 Jul 09];42(4):258-66. Available in: http://onlinelibrary.wiley.com/ doi/10.1363/4225810/pdf

13. Lin JD. Chen SF, Lin LP, Sung CL. Self-reports of Pap smear screening in women with physical disabilities. Res Dev Disabil [Internet]. 2011 [cited 2014 Ago 18];32(2):456-61. Available in: http://www.sciencedirect.com/science/article/ pii/S0891422211000035\#

Received: 25.01.2014

Approved: 10.11.2014 